\title{
Development of Learning Devices Using Discovery Model Based on Aceh Culture to Improve Understanding of Student Physics Concept
}

\author{
Yeninda Sartika \\ Physics Education Program \\ Postgraduate of Universitas Negeri \\ Medan (UNIMED) \\ Medan, Indonesia \\ yeninda92@gmail.com
}

\author{
Sahyar \\ Physics Education Program \\ Postgraduate of Universitas Negeri \\ Medan (UNIMED) \\ Medan, Indonesia
}

\author{
Derlina \\ Physics Education Program \\ Postgraduate of Universitas Negeri \\ Medan (UNIMED) \\ Medan, Indonesia
}

\begin{abstract}
Purposes of the study were to analyze the validity, practicality and effectiveness of learning devices using discovery learning model based on Aceh culture and to analyze the improvement understanding of students physics concept. This study was Research and Development (R\&D) by using 4-D model include define, design, develop, and disseminate stages proposed by Thiagarajan with limited trial. Learning devices were developed in the form of lesson plan, student worksheet, student's book, teacher's book and instrument understanding of student physic concept on kinematics motion straight material. All of the learning devices were based on Aceh Culture. Subjects in this study were students of class X MIA I MA Ulumul Quran Langsa. The result of the research shows that the learning devices using discovery learning model based on Aceh culture with an average total validity of lesson plan $=4.31$, student's book $=4.36$, teacher's book $=4.39$, student worksheet $=4.37$ and concept comprehension test instruments valid, practical and effective and understanding of students physics concepts increases with an average $\mathrm{N}$-gain of 0.35 with moderate qualifications.
\end{abstract}

Keywords - development, learning devices, discovery learning, Aceh culture, understanding of students' physics concept.

\section{INTRODUCTION}

Education and culture is something that cannot be avoided in everyday life, because culture is a whole and comprehensive whole that prevails in a society and education is a fundamental need for every individual in society. [1] states that education is an activity of receiving and giving knowledge so that culture can be passed on from generation to generation. Education and culture have a very important role in nurturing and developing noble values of the nation, which impact on the formation of characters based on the noble cultural values. As [2] states that culture is the embodiment of human character.

Based on the above explanation, it showed that the learning device has an important act in the success of the learning process. But the facts in MA Ulumul Quran Kota Langsa there are problems about this learning device, where the completeness of teacher learning tools basically has been complete, but the teachers still tend to use the same Learning Plan (RPP) for several years of learning that implicate the use of learning model keep repeating regardless of educational demands and changing the students characteristics. Teachers also tend to use teaching materials from publishers as the only one source of learning in the classroom and have not developed LKS in accordance with the learning objectives and learning models used. The impact of the preparation of learning tools that have not maximized automatically give some impact on the process of learning in the classroom.

Furthermore, based on interviews with one of the physics teachers, namely Mr. Taufik obtained that the quality of learning process and student achievement on physics subject is still relatively low. The low quality of process and learning achievement is indicated by the fact that students have difficulty learning on physics subject. Learning difficulties experienced by students one of them is the difficulty in understanding the basic concepts that exist in the subject of physics. This indicates that the students' understanding of physics concept is still low. And the difficulty of student learning is reflected from the result of study on daily test which is still relatively low under minimum completeness criteria, that is 75 . So it shows that the understanding of physics concept is not grown through the process of physics learning.

For that required a means of learning model that is able to make the establishment of cooperation among students in accordance with Aceh culture is expected to also be able to grow the character of each learner during the learning process is a learning model that can be applied by using group learning system. One of the learning models that can help teachers in directing students to be actively involved in the learning process is the discovery learning model. Previous research supporting the application of discovery learning in physics learning is the findings of [3] show that the development of Integrated IPA Module Theme of Discovery-based Substance Change To Improve Generic Skills And Students 'Learning Outcomes Students can improve students' generic skills and change the character of students to be more good.

Learning devices through discovery learning model integrated with cultural elements can be used as a solution in 
creating a contextual and meaningful learning for students. As [4] conducted a study on the importance of student culture that influences the learning process in school. Coupled with [5] also states that culture-based learning is a strategy for creating a learning environment and designing a learning experience that integrates culture as part of the learning process. Cultures that are integrated in learning tools must be in accordance with the culture of the students. Choosing Acehnese culture, especially in North Sumatera region consisting mostly of Acehnese ethnicity can be used as a supporter of the learning process that can be used as a hope in fostering students' interest to learn physics. As previous research [6] stated that by applying the learning model through problem solving originating from the facts and the cultural environment of Aceh, applying the pattern of socio-cultural interaction of Aceh as a learning strategy can improve student learning outcomes. And [7] also conducted a study that the ability to understand the concept of students can be improved by developing learning tools based on problem model based on Acehnese cultural context.

There are many things that can be developed from the Aceh culture including the cultural system of collaborative sense of collaboration that can be applied in learning through group discussions by dividing groups into 3 subgroups consisting of Keuchik, Tuha peut and ureung gampong working together to solve problems. The values or suggestions that exist in Aceh culture can also be used as motivation and role models. For example, Aceh ancestors advised parents to guide their children, namely "Ta ek u glee sama-sama, Ta trend $u$ aki gle pih sama-sama, udep tulong menulong, saket tajak saweu, watee lapang ngen susah ta rasa sama-sama". When associated with learning this suggestion means that the students' maximum abilities should not only depend on the teacher's ability but are achieved through interaction among fellow students through cooperation with other students and the environment. Based on the above background description, this study aims to: (1) produce learning tools through a discovery learning model based on Aceh culture that is valid, practical and effective; (2) to analyze the improvement of the ability of understanding the concept of physics by applying learning tools through discovery learning model based on Aceh culture.

\section{LITERATURE REVIEW}

\subsection{Understanding Concept}

Understanding the concept is the competence shown by students in understanding the concept and in performing a flexible, accurate, efficient, and appropriate procedure. Understanding of a concept is very important because if students master the concept of prerequisite materials then the students will be easy to understand the concept of the next material. One of the categories in the cognitive dimension of Bloom's revived cognitive taxonomy process proposed by [8] is to understand the meaning of constructing the meaning of instructional messages, whether spoken, written and graphic in learning, books or computer screens. Cognitive processes in the categories of understanding include (1) interpreting, (2) modeling, (3) classifying, (4) summarizing, (5) concluding, (6) comparing and (7) explaining.

\subsection{Learning Model Discovery based on Aceh culture}

Integrating discovery learning models and Aceh culture types in the learning process will create a meaningful learning atmosphere. It is very reasonable because the success of the learning process is strongly influenced by the cultural environment of students. Just as [9] states that in order for students to feel that the material they are learning is part of themselves, the learning must begin with a contextual learning of the culture in which the student is located. Then [6] argues that student activity is the information processing that is active and born in a social matrix, where the way of thinking, perceiving, and acting is influenced By culture, environment and Others around him.

Therefore learning model discovery based on Aceh culture is a learning model that teaches students to face academic, moral and social problems, so students are organized by doing joint research through discussion group learning integrated with Aceh culture value In solving problems related to physics learning.

\section{METHOD}

This research was the development by using 4-D model of development [10] that consists of four stages, namely stage define, design, develop and disseminate.

\subsection{Subject and Object}

The subjects in this study were students of class X MA Ulumul Quran Langsa city academic year 2017/2018, while the object of this study is a learning tool through the discovery of Aceh-based learning model of learning on the materials of straight motion kinematics and test instrument understanding the concept of physics students. The first experiments were conducted in class XI MIA-1 and the second trial was conducted in class X MIA-1.

\subsection{Instrument of Data Collection}

Instrument of data collection in this research is validation sheet, observation sheet, and test. The validation sheet is used to collect the review result data from the validator. Observation sheets are used to determine the implementation of learning, assessing the competence of attitudes, skills, and activities. Improved understanding of student physics concepts using N-Gain by [11].

\section{RESULT AND DISCUSSION}

The result of the research is the product of learning device through learning model discovery based on Aceh culture on straight motion kinematics. The results of research and discussion as follows:

The define stage is performed to define and define requirements in the learning process. This stage consists of the beginning-end analysis, student analysis, concept analysis, 
task analysis, and objectives specifications of learning. The results of the final analysis concluded that the required learning device that refers to the problem based learning model based on Aceh culture in the development of learning devices. The result of student's analysis is obtained that the student's academic skill is still low, the student's learning style which is active in the group as well as the background of the dominant tribe of Aceh students makes the learning device using the learning model discovery based on Aceh culture can be applied. Concept analysis is an analysis of the main concepts of the material to be taught. The result of task analysis obtained refers to the concept analysis and learning objectives based on Core Competence (KI) and Basic Competence $(\mathrm{KD})$ which have been established in accordance with the 2013 curriculum.

The design stage is done through test preparation and nontest, format selection, media selection and initial design of instructional devices. The results of the tests compiled in this study is a test of understanding the concept of physics. The results of the format selection in this study are adjusted to the curriculum of 2013, namely [12]. Furthermore, the Student Book format refers to the rules of BSNP (National Education Standards Board) and the format of LKS is adapted to the stages of learning and discovery model based on Aceh culture. The results of media selection or visual aids are used visual media in the form of physical culture of Aceh, in the form of drawing of PLTU vessel, game of meu creek which is played by girl, pen, ruler, stick, stopwatch and some object of Aceh Culture. The initial design results in the form of RPP, teacher book, student book and LKS for 3 times meeting as well as test instruments understanding the concept of physics.

Stage Develop aims to modify and develop learning devices that have been made in the previous stage of define and design. After the device is designed in the form of draft I, then at this stage tested the validity by expert validator and field trials. The test of learning device validation through discovery learning model based on Aceh culture in the form of RPP, LKS, teacher book and student book is done by expert of validator consisting of lecturer and teacher

TABLE 1. Validation Result by Expert of Validator

\begin{tabular}{ccc}
\hline Learning & Average of & Category \\
\hline RPP & 4,31 & Good \\
\hline LKS & 4,37 & Good \\
\hline Student's & 4,36 & Good \\
\hline Teacher's & 4,39 & Good
\end{tabular}

Table 1 summarizes that instructional devices in design I with various revisions have been used for experiments. In addition, the physics concept's comprehension test has been validated by an expert and declared valid with various revisions. The design of learning tools in the revised draft $\mathrm{I}$ is called draft II. This learning tool is ready to be tested in the field. Field trials were conducted twice, is trial I and trial II. These trials are conducted to determine the practicality and effectiveness of the developed learning tools. Learning devices are said to be practical if there is an expert statement that this device is worth using and the value of implementing learning using this device is good or very good [13][14][15]. While the effectiveness of learning tools seen from the students' learning mastery in the classic student activity and the responses given to the learning tools of students [13] [14] [15] [16] [17].

The experimental learning tool using the discovery model of Aceh based culture learning was conducted on 5 students of class XI MIA I MA Ulumul Quran. This research was conducted by researchers as teachers and two observers to observe the implementation of learning and student activities. Researchers have obtained the appropriate approval from experts to use learning tools in the second draft, then the learning implementation on the first test obtained an average of 2.99 and is still in sufficient category $(2<\mathrm{P} \leq 3)$.

Students' learning completeness is classical in the first test that is equal to $40 \%$, where the limit of effective criterion fulfillment is $75 \%$ of students complete [15]. Student activity increases at each meeting.

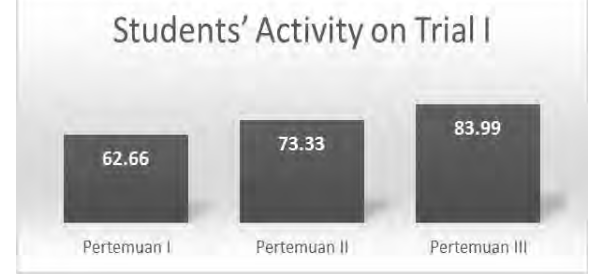

Fig 1. Students' Activity on Trial I

Figure 1 gives the conclusion that on average the overall activity of the student is still in enough category. Positive student response to learning device in this test is $83.88 \%$ where the effectiveness limit of $80 \%$ of students give positive response

Based on the above description it can be concluded that the device in draft II is not yet practical and has not been effective so it needs a revision based on analysis from trial I. The revised learning device is called draft III. Draft III is the final draft that will be in trial II.

Trial II was conducted in X class MIA I MA Ulumul Quran Langsa City with 24 students. Experiment II was conducted to measure draft III as a learning tool using an Aceh-based discovery-based learning model that meets all the established and practical criteria. The result of trial II that has been done can be concluded that learning device using learning model of discovery based on Aceh culture developed has fulfilled all the criteria of practical and effective that set. The practicality of instructional tools as measured by the validity and implementation of learning tools is better than experiment I.

TABLE 2. Score of Implementation of Learning Devices Trial II

\begin{tabular}{|c|c|c|c|c|c|}
\hline \multirow[t]{2}{*}{ Average } & \multicolumn{3}{|c|}{ Every Meet } & \multirow[t]{2}{*}{ Average } & \multirow[t]{2}{*}{ Category } \\
\hline & 1 & 2 & 3 & & \\
\hline Trial II & 4,09 & 4,23 & 4,46 & 4,26 & $\begin{array}{l}\text { Very } \\
\text { High }\end{array}$ \\
\hline
\end{tabular}

The overall learning device implementation in trial II is 4.26 , which, if referenced to the predefined instruction learning device criteria, then the average value of 4.26 is in very high category $(4<\mathrm{P} \leq 5)$.

The effectiveness of learning devices using discovery learning model based Aceh culture has fulfilled all the criteria set and can be said to be effective. 
TABLE 3. Level of Students Complete Learning by Classical Trial II

\begin{tabular}{|c|c|c|}
\hline \multirow{2}{*}{ Category } & \multicolumn{2}{|c|}{ Understanding the Concept of Physics } \\
\cline { 2 - 3 } & Total Students & Percentage \\
\hline Complete & 20 & $87,5 \%$ \\
\hline Not Complete & 4 & $12,5 \%$ \\
\hline Amount & 24 & $100 \%$ \\
\hline
\end{tabular}

If it is referenced in the classical student's completeness criterion, that is at least $80 \%$, it can be concluded that the post result of student physics concept conception in trial II has fulfilled the effective criteria that is $87,5 \%$ student have complete pursuing completeness in classical. Furthermore, student activity during the learning process using discovery learning model based on Aceh culture was done by observation.

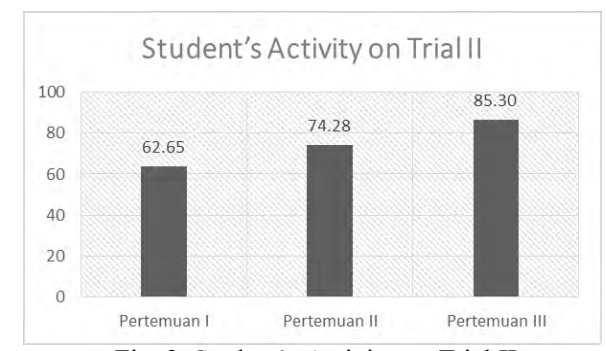

Fig. 2. Student's Activity on Trial II

Overall the average student activity has increased. Thus it can be concluded learning device using learning model discovery based on Aceh culture developed effectively in terms of student activity that has achieved improvement.

The student's response gave the average total positive response in the second try of $96.06 \%$. If the results of this analysis are referenced to the criteria set forth in chapter III, it can be concluded that the students' responses to the components and learning activities are positive. Based on the analysis of trial II data, it is known that the learning devices using learning model discovery based on Aceh culture has fulfilled all valid, practical and effective criteria. So there is no revision of draft III on instructional device that developed using learning model discovery based on Aceh culture on straight motion after trial II.

The disseminate stage is the final stage in the 4-D development model. At this stage, learning devices that have been piloted in the research class will be re-tested by comparing the developed learning device (experimental class) with the device used by physics subject teachers in MA Ulumul Quran Langsa City (control class). However, this stage is not carried out by researchers, due to time, cost and energy constraints so that this stage is not discussed in depth.

Data obtained from posttest result of understanding physics concept of student on trial II is analyzed to know the improvement of understanding physics concepts of students by comparing the average score of students obtained from posttest result of understanding physics concept of student each meeting on experiment II.
TABLE 4. N-Gain of Understanding Physic Concept

\begin{tabular}{|c|c|c|}
\hline Meet & N-gain & Category \\
\hline I & 0,28 & Low \\
\hline II & 0,35 & Medium \\
\hline III & 0,44 & Medium \\
\hline
\end{tabular}

Based on Table 4, the students 'understanding of physics concepts at each meeting increases so that it can be concluded that the application of learning tools using a learning model based on Aceh's culture-based learning can improve students' physics concept understanding.

\section{CONCLUSION}

Based on the results of the analysis and discussion in this study, it can be concluded that: 1) Validity of learning devices through learning model discovery based on Aceh culture has valid for use with average total validity RPP $=4.31$, Student's Book $=4.36$, Teacher's Books $=4.39$, LKS $=4.37$, as well as test understanding physic concept devices have also been valid based on the assessment by expert validators; 2) The practicality of learning model discovery based on Aceh culture has been easy to use in learning. This is based on the assessment of experts and observation of the implementation of learning with good category; 3) The effectiveness of learning devices using through learning model discovery based on Aceh culture has been said to be effective for use in learning. This is based on the completeness of learning has classically exceeded the minimum limit of $87.5 \%$ and student response has also been positive. 4) There is improvement of students' understanding of the concepts of physics students after applying the learning device using discovery learning model based Aceh culture on the material straight motion.

\section{REFERENCES}

[1] Butts, R.F. 1955. A Cultural History Of Western Education, Its Social and Intellectual Foundations. New York: McGraw-Hill Book Company.

[2] Widodo, 2013. The influence of Javanese Culture on The Education Curriculum in Indonesia. Journal of Education and Practice. Vol. $4 \mathrm{No}$. 19 hal 139-142.

[3] Septianu, dkk. 2014. Pengembangan modul ipa terpadu tema perubahan zat berbasis discovery untuk meningkatkan keterampilan Generik dan hasil belajar siswa. Unnes Science Education JournalUSEJ 3 (3) (2014).

[4] Wahyudi. "Overview of cultural aspects of science learning: the importance of science curriculum based on local culture," Journal of education and culture 4, pp. 42-59, 2003.

[5] Sardjiyo and P. Pannen, "Cultural learning: learning innovation model and implementation of competency-based curriculum," Educational journal 6, p. 83-97, 2005.

[6] Sinaga, B. 2007. Pengembangan Model Pembelajaran Matematika Berdasarkan Masalah Berbasis Budaya Batak (PBMB3). Disertasi. Surabaya : PPs Unesa.

[7] Aufa, M, Saragih, S dan Minarni, A. 2016. Development of Learning Devices through Problem Based Learning Model Based on the Context of Aceh Cultural to Improve Mathematical Communication Skills and Social Skills of SMPN 1 Muara Batu Students. Journal of Education and Practice. 7 (24): 232-248.

[8] Anderson, L.W \& Krathwohl, D.R. 2010. Kerangka Landasan Untuk Pembelajaran, Pengajaran, dan Assesmen. Yogyakarta: Pustaka Belajar. 
[9] Rohaeti, E. (2011), "Cultural Transformation Through Meaningful Mathematics Learning", Jurnal Pengajaran MIPA UPI Bandung 16.

[10] Thiagarajan, S. Semmel, DS. Semmel, M. (1974), "Instructional Development for Training Teachers of Exceptional Children A Sourse Book". Indiana: Indiana University.

[11] Hake, R. R. (1999). Analyzing Change/Gain Scores. American Educational Research Association's Division: 1-4.

[12] Permendikbud 2013, "Techniques and forms of assessment instruments Based on the 2013 curriculum, Online, March 2017.

[13] Nieveen, N. 2007. An Introduction to Education Design Research. China: The east China Normal University.

[14] Akker, J, V, D. (1999). Principle and Methods of Development Research. First Edition Illionis: F. E Peacock Publishers, Inc.

[15] Herman. (2012). Pengembangan Perangkat Pembelajaran Model Pengajaran Langsung untuk Mengajarkan Materi Kesetimbangan Benda Tegar. Jurnal Sains dan Pendidikan Fisika, (Online), Jilid 8 Nomor 1, April $2012 \mathrm{hlm}$ 1-11, (http://digilib.unm.ac.id/download.php?id=236, diakses 08 Oktober 2017).

[16] Reigeluth, C. M. (2000). What is instructional-design theory and how is it changing? Dalam: Reigeluth, C. M. (Ed.). Instructional-design theories and models: A new paradigm of instructional.

[17] Slavin, R. E. (2006). Educational Psychology, Theories and Practice. Eighth Edition. Masschusetts: Allyn and Bacon Publishers. 